\title{
Who benefits from mastery-approach and performance-approach goals in college? Students' social class as a moderator of the link between goals and grade
}

\author{
Céline Darnon
}

Mickaël Jury

Cristina Aelenei

This paper has been accepted for publication in European Journal of Psychology of Education in 2018. This version is a post-print.

Correspondence concerning this article should be addressed to Céline Darnon, celine.darnon@uca.fr.

\begin{abstract}
Although approach forms of achievement goals (mastery and performance goals) have been shown to predict academic achievement in college, recent research underscores that these associations are rather weak and not consistently observed. The present study tests students' social class (in the present research, generational status) as a moderator of the relationships between both masteryapproach goals and performance-approach goals and final grade. One hundred students (45 firstgeneration students and 55 continuing-generation students, $M_{a g e}=18.9, S D=1.52$ ) answered an achievement goal scale related to one of their classes at the beginning of the year. Their final grade for this class was obtained three months later. As expected, performance-approach goals positively predicted final grade only for upper- class students, while mastery-approach goals tend to do so for lower-class students, supporting the idea that different kinds of motivation could predict students' achievement depending on their social class.
\end{abstract}

Keywords: Achievement goals, Achievement, Social class, First-generation, College 
In achievement goal literature, approach forms of motivation are usually seen as relevant and positive motivations for achieving performance, especially in the college context (Darnon et al. 2009; Van Yperen et al. 2014). Indeed, trying to understand and learn (i.e., mastery-approach goals) and trying to outperform others (i.e., performance-approach goals) have both been documented as positive predictors of academic success (Harackiewicz et al. 1997; Senko et al. 2011). However, as evidenced in this debate, empirical data do not always support this claim. Meanwhile, several authors in the area have called for more research considering demographic variables, including social class $^{1}$, in order to understand better which goals predict academic success, when, and why (Darnon et al. 2012; Huang 2012; Darnon et al. 2008). The present paper examines social class as a moderator of the link between both mastery-approach and performance- approach goals and academic performance in the college context.

Achievement goals and academic grades

Since its origin in the 1980s (Dweck 1986; Elliott and Dweck 1988; Nicholls 1984), achievement goal theory has been the subject of abundant research to examine the consequences of goal pursuit in the classroom. According to this research, in an achievement task, students can pursue either mastery goals (i.e., desire to learn, to improve one's knowledge and ability) or performance goals (i.e., drive to demonstrate superior performance relative to others). In the 1990s, research further documented that mastery and performance goals could be either approach or avoidance oriented (Elliot and Church 1997; Elliot and McGregor 2001; Elliot et al. 1999). In particular, performance-approach goal individuals are oriented toward the demonstration of superior ability, whereas performanceavoidance-oriented individuals want to avoid performing more poorly than others. Moreover, mastery-approach goals are oriented toward the search for self-improvement and learning, whereas mastery-avoidance goals are associated with the fear of not performing as well as one did in the past. Research has shown that avoidant forms of goals are generally related to poor achievement outcomes (Elliot and Church 1997; Elliot and McGregor 2001; Linnenbrink-Garcia et al. 2008). On the contrary, both approach forms of goals have been shown to be positively associated with academic performance, particularly for college students. Indeed, although mastery-approach goals and performance-approach goals are related to different patterns of outcomes (e.g., cooperative behaviors, deep studying, and high efforts for mastery goals; competitive behaviors, surface processing, and cheating for performance goals; Anderman and Danner 2008; Elliot and McGregor 1999; see Senko et al. 2011, for a review), recent meta-analyses found that both were positively related to academic grades (Huang 2012; Hulleman et al. 2010; Van Yperen et al. 2014). Interestingly, these meta-analyses also highlighted that these links exist but were quite small, suggesting the existence of potential moderators. In the present paper, we argue that, in a higher education context, social class may moderate the effect of both types of goals on academic grades.

Lower-class and upper-class students in college

Social class influences many life outcomes (for reviews, see Fiske and Markus 2012; Goudeau et al. 2017; Kraus et al. 2011, 2012). In particular, an important line of research has documented that, in the context of higher education, lower-class students experience many more difficulties than their upperclass counterparts (for reviews, see Jury et al. 2017; Stephens et al. 2014). More specifically, behaviors, vocabulary, and habits that are valued in the higher education context are more in line with those developed in families that belong to dominant classes than with values developed in unprivileged classes (Bourdieu et al. 1990). Consequently, lower-class students develop a sense of "incompatibility"

\footnotetext{
${ }^{1}$ A student's social class refers to his or her family's rank in the society. In the social class literature, various measures such as income, parental level of education, or occupation have been used to identify one's social class. In the present paper, we will specifically focus on students' parental level of education.
} 
within the college context (Jetten et al. 2008; Johnson et al. 2011; Ostrove and Long 2007). When attending college, lower-class students feel less socially integrated (Rubin 2012), have a lower sense of belonging (Ostrove and Long 2007), are less engaged (Stebleton and Soria 2012), face more obstacles (Stebleton et al. 2014), and have more intentions to quit (Johnson et al. 2011; Langhout et al. 2009) as well as lower academic performances (OECD 2014; Sirin 2005) than their upper-class counterparts. More recently, Stephens and colleagues (Stephens et al. 2012a, b) demonstrated that lower-class students experience a mismatch between the values they have developed as members of low-status groups and those promoted in college culture. This mismatch further impairs their academic grades. In addition, lower-class students are the targets of a negative stereotype concerning their abilities (Croizet and Claire 1998; Régner et al. 2002; Spencer and Castano 2007). Thus, in academic contexts, lower-class students are likely to experience a stereotype threat (Croizet and Claire 1998; Croizet et al. 2001; Harrison et al. 2006; Spencer and Castano 2007). For all these reasons, lower-class students also have a lower self-esteem (Twenge and Campbell 2002), lower self- efficacy (Gecas 1989; Ramos-Sánchez and Nichols 2007), lower self-assessed intelligence (Ivcevic and Kaufman 2013; Kudrna et al. 2010), and lower expectancies of success (Johnson et al. 2011; Langhout et al. 2009) than upperclass students.

Social class as a moderator of the goals-performance links

Interestingly, in the achievement goal field, the uncertainty regarding one's success has often been argued to moderate both the performance-approach goals-grade link and the mastery-approach goals-grade link. In particular, it has been shown that mastery goals favor performance when participants were exposed to failures (Covington and Omelich 1984), on de- manding tasks (Graham and Golan 1991) and on difficult exams (e.g., Elliot and McGregor 1999; Grant and Dweck 2003). Mastery goal benefits are also more often documented when the assigned goal is difficult (Jagacinski et al. 2001) rather than easy to reach (see also Utman's meta-analysis, 1997). Likewise, it seems that performance goals positively impact achievement on simple or well-learnt tasks (Steele-Johnson et al. 2000), but no longer do so when the task is more difficult (Grant and Dweck 2003) or-although still subject to controversy (e.g., Harackiewicz et al. 1997)-when students perceive their ability as low (Elliott and Dweck 1988; Jagacinski et al. 2001; Nicholls 1984; Smiley and Dweck 1994). In the same vein, some authors (Darnon et al. 2007) have shown that the advantage of mastery goals over performance-approach goals on learning only appeared when a co-actor made participants doubt the validity of their own answers. Thus, the extent to which a person doubts his or her ability to succeed seems to moderate both the performance-approach goals-grade link and the mastery-approach goals-grade link, but in the opposite direction.

It has sometimes been argued in the field (e.g., Nicholls 1989) that an education centered on mastery goals should favor all students rather than just privileged groups. In line with this idea, some sparse research suggests that low-status individuals benefit from mastery-approach goals whereas highstatus individuals benefit from performance-approach goals. For example, women, more than men, suffer from the effects of performance-approach goals (Jagacinski et al. 2008; see also Midgley et al. 2001, for a discussion of this point) and benefit from mastery goal inductions (Patrick et al. 1999). Mastery-approach goals, but not performance- approach goals, have also been shown to reduce women's social identity threat (Stout and Dasgupta 2013). More recently, in the college context, Smeding et al. (2013) tested social class as a moderator of the effect of different goal-based forms of assessment. Assessment was either presented as a tool for education (mastery oriented) or as a tool for selection (performance oriented). This research indicated that lower-class students are those who perform better after mastery-based forms of assessments than after performance-based goals assessments (see Souchal et al. 2014, for a similar pattern on girls' performance on a scientific task) and those whose self-set mastery goals were the most strongly related to exam grade. 


\section{Overview and hypotheses}

The present study measures mastery-approach and performance-approach goals at the beginning of the semester and tests them as predictors of the final grade obtained at the end of the class (three months later). As in most research in the area, students' social class is measured by generational status (Harackiewicz et al. 2014; Jury et al. 2015; Stephens et al. 2012a). Generational status should moderate both the effect of mastery-approach goals and the effect of performance-approach goals on final grade but in the reverse direction: The positive link between performance-approach goals and exam grade should be stronger for continuing- generation students (i.e., upper-class students) than for firstgeneration students (i.e., lower- class students), whereas the positive link between mastery-approach goals and academic performance should be stronger for first-generation students than for continuinggeneration students.

\section{Method}

Participants and procedure

Participants were 103 undergraduate psychology students who volunteered to participate in the context of their methodology class. Because of two missing data on the covariate and one missing data on the social class measure, our final sample was composed of 100 participants, 90 women and 10 men, with a mean age of 18.9 years $(S D=1.52)$. Participants responded to the achievement goal scale and the demographic questions during one of their introductory level methodology lectures that took place at the beginning of the fall semester. At the end of the semester, three months later, the grade obtained for this methodology class was recorded ${ }^{2}$.

\section{Measures}

Achievement goals. The performance and mastery goal items were extracted from Elliot and McGregor's (2001) Achievement Goal Questionnaire (see Darnon \& Butera 2005 for the French version). Participants were asked to report the extent to which they endorsed mastery-approach goals $(\alpha=.86, M=5.62, S D=1.17)$ and performance-approach goals $(\alpha=.86, M=3.68, S D=1.59)$ in the methodology class. Both measures contained three items, and participants' answers ranged from 1 "not at all true of me" to 7 "very true of me" (e.g., "It is important for me to do better than other students" for performance-approach goals; "I want to learn as much as possible from this class" for mastery-approach goals).

Social class. Participants reported their mothers' and fathers' highest degrees. If the highest degree reached by a participant's parents was lower than the baccalauréat (i.e., the French high-school exit exam), the participant was coded as first-generation students. If at least one of the student's parents had earned the baccalaureat or a higher degree, the student was categorized as a continuinggeneration student (see Jury et al. 2015, for a similar classification). Based on this classification, 45 students were coded as first-generation students and 55 as continuing-generation students.

Final grade. The final grade was the grade obtained in this specific introductory level method- ology class and corresponded to the mean of two exams students took at the end of the semester, three months later. First, they had to work on a methodological project (7 pages maximum) and present this project orally. This part counted for $20 \%$ of the final grade. Second, they had to take a test containing

\footnotetext{
2 This research was part of a large study. Only the measures that are relevant for the present hypothesis are discussed here
} 
15 open-ended questions on the content of the entire class. The final grade could range from 0 (minimum) to 20 (maximum; current range 4.18 to $18.75, M=12.17, S D=3.38$ ).

Initial academic abilities. As participants were at the beginning of their studies, we asked them to report the grade they obtained on the high-school exit exam (baccalauréat), which could range from 10 (passing level) to $20(\mathrm{M}=11.69, \mathrm{SD}=1.41$; current range from 10 to 16$)$. Intercorrelations among variables are presented in Table 1.

\begin{tabular}{|c|c|c|c|c|c|c|}
\hline & 1 & 2 & 3 & 4 & $\begin{array}{l}M \text { and SD (in brackets) } \\
\text { Lower-class }\end{array}$ & $\begin{array}{l}M \text { and SD (in brackets) } \\
\text { Upper-class }\end{array}$ \\
\hline $\begin{array}{l}\text { 1. Baccalauréat grade } \\
\text { 2. Performance-approach goals } \\
\text { 3. Mastery-approach goals } \\
\text { 4. Exam grade } \\
\text { 5. Social class }\end{array}$ & $\begin{array}{l}.13 \\
.16 \\
.32^{* *} \\
.16\end{array}$ & $\begin{array}{l}.38 * * \\
.17 \\
-.04\end{array}$ & $\begin{array}{l}.18 \\
.06\end{array}$ & -.06 & $\begin{array}{r}11.46(1.31) \\
3.74(1.62) \\
5.53(1.04) \\
12.41(3.27)\end{array}$ & $\begin{array}{r}11.91(1.46) \\
3.63(1.61) \\
5.67(1.27) \\
11.99(3.51)\end{array}$ \\
\hline
\end{tabular}

Results

Regression analyses were conducted to test whether mastery- and performance-approach goals interacted with generational status to predict final grade. These regression analyses included three predictors-generational status (coded - 0.5, first-generation students; +0.5 , continuing- generation students), performance-approach goals (mean centered), and mastery-approach goals (mean centered) - as well as all possible interactions among these three terms. To control for initial abilities, the baccalaureate grade (mean centered) was entered as a covariate. As the covariate was not correlated to any of the predictors, the interaction between the covariate and the predictors was not entered in the analyses (Yzerbyt et al. 2004).

None of the main effects was significant: $\beta=.11, F(1,91)<1$ for performance-approach goals; $\beta=.14$, $F(1,91)=1.46, p=.23$ for mastery-approach goals; and $\beta=-.05, F(1,91)<1$ for social class, except for the main effect of the covariate, $\beta=.31, F(1,91)=10.23, p<.003, \eta_{p}^{2}=.10,95 \% \mathrm{Cl}[.28,1.21]$. More importantly, as expected, performance-approach goals interacted with social class: $\beta=.23, F(1$, $91)=4.47, p<.04, \eta_{p}^{2}=.05,95 \% \mathrm{Cl}[.06,1.93]$. This interaction is depicted in Fig. 1 . Simple slope analyses revealed that performance- approach goals positively predicted academic grade for continuing-generation students, $\beta=.34, F(1,91)=4.75, p<.04, \eta_{p}^{2}=.08,95 \% \mathrm{Cl}[.06,1.38]$, but not for first-generation students, $\beta=-.13, F(1,91)<1$. The interaction between mastery-approach goals and social class was marginal and in the reverse direction, $\beta=-.22, F(1,91)=3.71, p<.06, \eta_{p}{ }^{2}=.04$, $95 \% \mathrm{Cl}[-2.59, .04]$. This interaction is depicted in Fig. 2. Simple slope analyses revealed that masteryapproach goals positively predicted academic grade for first-generation students, $\beta=.36, F(1,91)=$ $4.01, p<.05,95 \% \mathrm{Cl}[.01,2.07]$, but not for continuing-generation students, $\beta=-.08, F(1,91)<1$. No other interaction was significant, all $F(1,91)<1$. 

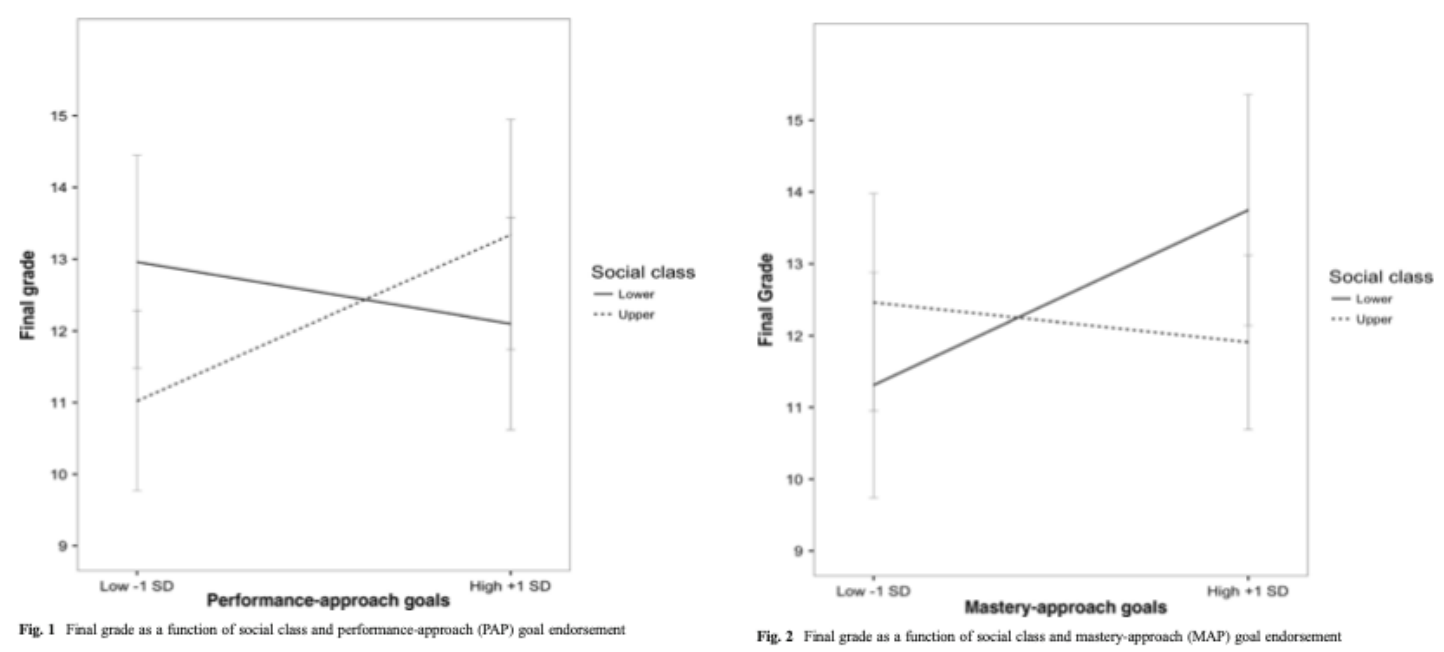

\section{Discussion}

The purpose of the present paper was to test social class as a moderator of the link between both mastery-approach goals and grade and performance-approach goals and grade. As developed above, in the higher education context, notably because of an experienced mismatch and of a negative stereotype, lower-class students are led to doubt their ability to succeed more than upper-class students (Croizet and Claire 1998; Gecas 1989; Ivcevic and Kaufman 2013; Stephens et al. 2012a). As mastery goals have been shown to positively predict achievement on difficult and challenging tasks or when students experience threat, failures, and conflicts, we argued that lower-class (i.e., first generation) students, but not upper-class (i.e., continuing generation) students, should benefit from a high endorsement of mastery goals. Moreover, as performance-approach goals have been shown to predict grade mostly in low-uncertainty situations, we predicted that performance-approach goals would be more positively related to grade for upper-class students than for lower-class students.

Results obtained in the present study bring initial support to these hypotheses. Indeed, the effect of performance-approach goals on final grade was moderated by social class. The positive link between performance-approach goals and final grade is only observed for continuing-generation students. The effect of mastery-approach goals on final grade was also (although marginally) moderated by social class. Mastery-approach goals were indeed positively associated to final grade for first-generation but not for continuing-generation students. In line with recent research in the area, the present results support the idea that not all approach goals are beneficial for all students. In particular, as observed several times in the literature, if performance-approach goals are positively related to grade (Harackiewicz et al. 2002; Hulleman et al. 2010; Senko et al. 2011; Van Yperen et al. 2014), it seems to be the case only for upper-class students-namely, the population that is the most often examined in the literature. Indeed, upper-class students usually largely outnumber lower-class students in the college context (Hearn and Rosinger 2014; OECD 2014). This positive association no longer exists for lower-class students. In the same vein, the general low association observed between masteryapproach goals and grade in the literature may be due to the fact that the sample examined in the previous research was mainly composed of upper-class students enrolled in universities. The present results suggest that mastery goals could be much more useful for lower- class students.

Interestingly, authors in the area have recently started to argue that goals should not be examined in a social vacuum and that more attention should be devoted to the social belonging of students (Berger and Archer 2016; Darnon et al. 2012; Huang 2012; Jury et al. 2015). The present study confirms that taking into account students' social class can help understand important inconsistencies or weak effect sizes observed in previous research (Hulleman et al. 2010; Van Yperen et al. 2014). The present results 
are consistent with recent research showing that the effects of performance goal- or mastery goaloriented contexts depend on social class (Smeding et al. 2013) by showing that similar moderation can also be observed with self-set goals and while controlling for initial academic ability. Thus, taken together, these studies suggest that a strong focus on mastery versus performance goals, regardless of the origin of this focus (contextual incentive in previous studies, personal self-set goals in the present study), can affect the experience of lower- and upper-class students differently in the context of higher education.

Some limitations should be noted. In particular, in the present data, both goals and social class are invoked variables. Therefore, causality cannot be established. Although situationally induced goals usually raise similar results as self-set goals (Linnenbrink-Garcia et al. 2008; Van Yperen et al. 2014, 2015), replicating the present results with manipulated goals would nicely complement the present findings. The low sample size is another important limitation of the present research. In addition, social class was measured through generational status. Although this is very common in the literature, such a measure prevents from examining middle social class students, who may be particularly concerned with upward mobility. Future research should examine this issue and should also measure avoidance goals in addition to approach goals. Indeed, lower-class students are likely to endorse performanceavoidance goals (Jury et al. 2015; Jury et al. 2015). Performance-avoidance goals have been shown to negatively predict academic performance (e.g., Elliot and Church 1997). Thus, it seems reasonable to assume that they may mediate the relationship between social class and poor academic performance. Moreover, in the present paper, it is argued that the reason why social class moderates the effects of goals is that social class affected the perception students have of their own chances to succeed within the university system. However, this perception was not measured in the present study, keeping open the question of what psychological processes mediate the findings. A concurrent explanation of the moderation of the mastery-approach goals-performance link could be the social value attached to mastery-approach goals among lower- and upper-class students. Indeed, recent research has documented that the more the goals are perceived as socially useful to succeed within the college context, the more they predict academic achievement (Dompnier et al. 2009, 2013; Dompnier et al. 2015). The same line of research has also shown that the higher the goals are perceived as socially desirable, the lower these goals predict academic performances. One could argue that mastery goals are more socially useful for lower-class students than for upper-class students and more socially desirable for upper-class students than for lower-class students. Indeed, because of poorer initial acquaintance with the system, succeeding in college is more challenging for lower-class than for upperclass students. Thus, as they cannot rely upon other resources (e.g., parental support), learning (i.e., mastery goals) may be perceived as the only useful way to reach academic success. This would imply that lower-class students endorse mastery goals for "true" reasons-namely, because they think these goals are required to succeed within the college context. Upper-class students may have other reasons to endorse mastery-approach goals. Indeed, mastery goals are particularly high in social desirability (Darnon et al. 2009). As upper-class students are usually more aware of college expectations (Collier and Morgan 2008), they may report goals for social desirability purposes. This could explain the low association between mastery-approach goals and performance for upper-class students. In other words, mastery-approach goals may be strongly associated with the performance of lower-class students because lower-class students endorse these goals for "true" reasons (i.e., because they believe in their social utility), more so than upper-class students who might endorse these goals for self-presentation purposes (i.e., because they know these goals are high in social desirability). Future research should test this possibility.

Interestingly, some authors have noted that, because of the selection function fulfilled by the university system in Western countries, performance-approach goals are particularly strongly promoted in higher education contexts (Alon 2009; Dompnier et al. 2008; Dornbusch et al. 1996; Jury et al. 2017). Besides, in the competitive context of higher education, performance-approach goals are often positively related to academic achievement (e.g., Harackiewicz et al. 2002). However, the 
present findings suggest that they are not beneficial for all students. Based on the present results and in line with previous research (Smeding et al. 2013), we believe that the strong promotion of performance-approach goals in higher education could probably explain why higher education fails to reduce the social class achievement gap. Indeed, by promoting goals that mostly serve upper-class students, the higher education environment contributes to acting in favor of upper-class students, leaving behind students who precisely deserve more attention-namely, students who would benefit the most from more mastery-oriented practices.

\section{References}

Alon, S. (2009). The evolution of class inequality in higher education: competition, exclusion, and adaptation. American Sociological Review, 74(5), 731-755. https://doi.org/10.1177/000312240907400503.

Anderman, E. M., \& Danner, F. (2008). Achievement goals and academic cheating. International Review of Social Psychology, 21(1), 155-180 Retrieved from www.cairn.info/revue-internationale-depsychologie- sociale-2008-1-page-155.htm.

Berger, N., \& Archer, J. (2016). School socio-economic status and student socio-academic achievement goals in upper secondary contexts. Social Psychology of Education, 19(1), 175-194. https://doi.org/10.1007/s11218- 015-9324-8.

Bourdieu, P., Passeron, J.-C., \& Nice, R. (1990). Reproduction in education, society and culture (2nd ed.). Thousand Oaks: Sage. Retrieved from http://search.ebscohost.com/login.aspx?direct=true\&db= psyh\&AN=1990-98996-000\&lang=fr\&site=ehost-live \&scope $=$ cite.

Collier, P. J., \& Morgan, D. L. (2008). "Is that paper really due today?": differences in first-generation and traditional college students' understandings of faculty expectations. Higher Education, 55(4), 425446. https://doi.org/10.1007/s10734-007-9065-5.

Covington, M. V., \& Omelich, C. L. (1984). Task-oriented versus competitive learning structures: motivational and performance consequences. Journal of Educational Psychology, 76(6), 1038-1050. https://doi. org/10.1037/0022-0663.76.6.1038.

Croizet, J.-C., \& Claire, T. (1998). Extending the concept of stereotype threat to social class: the intellectual underperformance of students from low socioeconomic backgrounds. Personality and Social Psychology Bulletin, 24(6), 588-594. https://doi.org/10.1177/0146167298246003.

Croizet, J.-C., Désert, M., Dutrévis, M., \& Leyens, J.-P. (2001). Stereotype threat, social class, gender, and academic under-achievement: when our reputation catches up to us and takes over. Social Psychology of Education, 4(3-4), 295-310. https://doi.org/10.1023/A:1011336821053.

Darnon, C., \& Butera, F. (2005). Buts d'accomplissement, stratégies d'étude, et motivation intrinsèque : présentation d'un domaine de recherche et validation française de l'échelle d'Elliot et McGregor (2001). [Achievement goals, study strategies, and intrinsic motivation: Presentation of a research field and French validation of the Elliot et McGregor (2001)'s scale. L'Année Psychologique, 105, 105-131.

Darnon, C., Butera, F., \& Harackiewicz, J. M. (2007). Achievement goals in social interactions: Learning with mastery vs. performance goals. Motivation and Emotion, 31, 61-70. 
Darnon, C., Butera, F., \& Harackiewicz, J. M. (2008). Toward a clarification of the effects of achievement goals. International Review of Social Psychology, 21, 5-18.

Darnon, C., Dompnier, B., Delmas, F., Pulfrey, C., \& Butera, F. (2009). Achievement goal promotion at University: Social desirability and social utility of mastery and performance goals. Journal of Personality and Social Psychology, 96, 119-134. https://doi.org/10.1037/a0012824.1

Darnon, C., Dompnier, B., \& Poortvliet, M. (2012). Achievement goals in educational contexts. A social psychology perspective. Social \& Personality Psychology Compass, 6(10), 760-771. https://doi. org/10.1111/j.1751-9004.2012.00457.x.

Dornbusch, S. M., Glasgow, K. L., \& Lin, I.-C. (1996). The social structure of schooling. Annual Review of Psychology, 47, 401-429. https://doi.org/10.1146/annurev.psych.47.1.401.

Dompnier, B., Darnon, C., \& Butera, F. (2009). Faking the desire to learn: A clarification of the link between mastery goals and academic achievement. Psychological Science, 20, 939-943.

Dompnier, B., Darnon, C., \& Butera, F. (2013). When performance-approach goals predict academic achieve- ment and when they do not: A social value approach. British Journal of Social Psychology, 52, 587-596.

Dompnier, B., Darnon, C., Delmas, F., \& Butera, F. (2008). Achievement goals and social judgment: The performance-approach goals paradox. International Review of Social Psychology, 21, 247-271.

Dompnier B., Darnon C.,Meier E., Brandner C., Smeding A., Butera F. (2015). Improving low achievers' academic performance at university by changing the social value of mastery goals. American Educational Research Journal, 52(4), 720-749

Dweck, C. S. (1986). Motivational processes affecting learning. American Psychologist, 41(10), 10401048. https://doi.org/10.1037/0003-066X.41.10.1040.

Elliot, A. J., \& Church, M. (1997). A hierarchical model of approach and avoidance achievement motivation. Journal of Personality and Social Psychology, 72(1), 218-232. https://doi.org/10.1037/0022-3514.72.1.218.

Elliot, A. J., \& McGregor, H. A. (1999). Test anxiety and the hierarchical model of approach and avoidance achievement motivation. Journal of Personality and Social Psychology, 76(4), 628-644. http://dx.doi. org/10.1037/0022-3514.76.4.628.

Elliot, A. J., \& McGregor, H. A. (2001). A $2 \times 2$ achievement goal framework. Journal of Personality and Social Psychology, 80(3), 501-519. https://doi.org/10.1037/0022-3514.80.3.501.

Elliot, A. J., McGregor, H. A., \& Gable, S. L. (1999). Achievement goals, study strategies, and exam performance: a mediational analysis. Journal of Educational Psychology, 91(3), 549-563. https://doi.org/10.1037/0022-0663.91.3.549.

Elliott, E. S., \& Dweck, C. S. (1988). Goals: an approach to motivation and achievement. Journal of Personality and Social Psychology, 54(1), 5-12 Retrieved from http://www.ncbi.nlm.nih.gov/pubmed/3346808. 
Fiske, S. T., \& Markus, H. R. (2012). Facing social class: how societal rank influences interaction (p. 272). New York: Russell Sage Foundation.

Gecas, V. (1989). The social psychology of self-efficacy. Annual Review of Sociology, 15, 291-316. https://doi.org/10.1146/annurev.so.15.080189.001451.

Goudeau, S., Autin, F., \& Croizet, J.-C. (2017). Studying, measuring and manipulating social class in social psychology: economic, symbolic and cultural approaches. International Review of Social Psychology, 30, 1- 19. https://doi.org/10.5334/irsp.52.

Graham, S., \& Golan, S. (1991). Motivational influences on cognition: task involvement, ego involvement, and depth of information processing. Journal of Educational Psychology, 83(2), 187-194. https://doi. org/10.1037/0022-0663.83.2.187.

Grant, H., \& Dweck, C. S. (2003). Clarifying achievement goals and their impact. Journal of Personality and Social Psychology, 85(3), 541-553. https://doi.org/10.1037/0022-3514.85.3.541.

Harackiewicz, J. M., Barron, K. E., Carter, S. M., Lehto, A. T., \& Elliot, A. J. (1997). Predictors and consequences of achievement goals in the college classroom: maintaining interest and making the grade. Journal of Personality and Social Psychology, 73(6), 1284-1295. https://doi.org/10.1037/00223514.73.6.1284.

Harackiewicz, J. M., Barron, K. E., Pintrich, P. R., Elliot, A. J., \& Thrash, T. M. (2002). Revision of achievement goal theory: necessary and illuminating. Journal of Educational Psychology, 94(3), 638635. https://doi. org/10.1037/0022-0663.94.3.638.

Harackiewicz, J. M., Canning, E. A., Tibbetts, Y., Giffen, C. J., Blair, S. S., Rouse, D. I., \& Hyde, J. S. (2014). Closing the social class achievement gap for first-generation students in undergraduate biology. Journal of Educational Psychology, 106(2), 375-389. https://doi.org/10.1111/j.14679280.1992.tb00019.x.

Harrison, L. A., Stevens, C. M., Monty, A. N., \& Coakley, C. A. (2006). The consequences of stereotype threat on the academic performance of White and non-White lower income college students. Social Psychology of Education, 9(3), 341-357. https://doi.org/10.1007/s11218-005-5456-6.

Hearn, J. C., \& Rosinger, K. O. (2014). Socioeconomic diversity in selective private colleges: an organizational analysis. The Review of Higher Education, 38, 71-104. https://doi.org/10.1353/RHE.2014.0043.

Huang, C. (2012). Discriminant and criterion-related validity of achievement goals in predicting academic achievement: a meta-analysis. Journal of Educational Psychology, 104(1), 48-73. https://doi.org/10.1037 /a0026223.

Hulleman, C. S., Schrager, S. M., Bodmann, S. M., \& Harackiewicz, J. M. (2010). A meta-analytic review of achievement goal measures: different labels for the same constructs or different constructs with similar labels? Psychological Bulletin, 136(3), 422-449. https://doi.org/10.1037/a0018947.

Ivcevic, Z., \& Kaufman, J. C. (2013). The can and cannot do attitude: how self-estimates of ability vary across ethnic and socioeconomic groups. Learning and Individual Differences, 27, 144-148. https://doi. org/10.1016/j.lindif.2013.07.011. 
Jagacinski, C. M., Kumar, S., \& Kokkinou, I. (2008). Challenge seeking: the relationship of achievement goals to choice of task difficulty level in ego-involving and neutral conditions. Motivation and Emotion, 32(4), 310-322. https://doi.org/10.1007/s11031-008-9103-3.

Jagacinski, C. M., Madden, J. L., \& Reider, M. H. (2001). The impact of situational and dispositional achievement goals on performance. Human Performance, 14(4), 321-337. https://doi.org/10.1207 /S15327043HUP1404_3.

Jetten, J., Iyer, A., Tsivrikos, D., \& Young, B. M. (2008). When is individual mobility costly? The role of economic and social identity factors. European Journal of Social Psychology, 38(5), 866-879. https://doi. org/10.1002/ejsp.471.

Johnson, S. E., Richeson, J. A., \& Finkel, E. J. (2011). Middle class and marginal? Socioeconomic status, stigma, and self-regulation at an elite university. Journal of Personality and Social Psychology, 100(5), 838-852. https://doi.org/10.1037/a0021956.

Jury, M., Darnon, C., Dompnier, B., \& Butera, F. (2017). The social utility of performance-approach goals in a selective educational environment. Social Psychology of Education: An International Journal.

Jury, M., Smeding, A., Court, M., \& Darnon, C. (2015). When first-generation students succeed at university: On the link between social class, academic performance, and performance-avoidance goals. Contemporary Educational Psychology, 41, 25-36.

Jury, M., Smeding, A., \& Darnon, C. (2015). First-generation students' underperformance at university: the impact of the function of selection. Frontiers in Pyschology, 6. https://10.3389/fpsyg.2015.00710.

Jury, M., Smeding, A., Stephens, N. M., Nelson, J. E., Aelenei, C., \& Darnon, C. (2017). The Experience of Low-SES Students in Higher Education: Psychological Barriers to Success and Interventions to Reduce Social-Class Inequality. Journal of Social Issues. https://doi.org/10.1111/josi.12202.

Kraus, M. W., Piff, P. K., \& Keltner, D. (2011). Social class as culture: the convergence of resources and rank in the social realm. Current Directions in Psychological Science, 20(4), 246-250. https://doi.org/10.1177 /0963721411414654.

Kraus, M. W., Piff, P. K., Mendoza-Denton, R., Rheinschmidt, M. L., \& Keltner, D. (2012). Social class, solipsism, and contextualism: how the rich are different from the poor. Psychological Review, 119(3), 546- 572. https://doi.org/10.1037/a0028756.

Kudrna, L., Furnham, A., \& Swami, V. (2010). The influence of social class salience on self-assessed intelligence. Social, Behavior and Personality, 38(6), 859-864. https://doi.org/10.2224 /sbp.2010.38.6.859.

Langhout, R. D., Drake, P., \& Rosselli, F. (2009). Classism in the university setting: examining student antecedents and outcomes. Journal of Diversity in Higher Education, 2(3), 166-181. https://doi. org/10.1037/a0016209.

Linnenbrink-Garcia, L., Tyson, D. F., \& Patall, E. A. (2008). When are achievement goal orientation beneficial for academic achievement? A closer look at main effects and moderating factors. International Review of Social Psychology, 21, 21-70. Retrieved from http://www.cairn.info/revueinternationale-de-psychologie- sociale-2008-1-page-19.html. 
Midgley, C., Kaplan, A., \& Middleton, M. (2001). Performance-approach goals: good for what, for whom, under what circumstances, and at what cost? Journal of Educational Psychology, 93(1), 77-86. https://doi. org/10.1037//0022-0663.93.1.77.

Nicholls, J. G. (1984). Achievement motivation: conceptions of ability, subjective experience, task choice, and performance. Psychological Review, 91(3), 328-346. https://doi.org/10.1037/0033295X.91.3.328.

Nicholls, J. G. (1989). The competitive ethos and democratic education. Cambridge: Harvard University Press.

OECD. (2014). Education at a glance: OECD indicators (p. 567). Paris: OECD Publishing. https://doi.org/10.1787/eag-2014-en.

Ostrove, J. M., \& Long, S. M. (2007). Social class and belonging: implications for college adjustment. The Review of Higher Education, 30(4), 363-389. https://doi.org/10.1353/rhe.2007.0028.

Patrick, H., Ryan, A. M., \& Pintrich, P. R. (1999). The differential impact of extrinsic and mastery goal orientations on males' and females' self-regulated learning. Learning and Individual Differences, 11(2), 153-171. https://doi.org/10.1016/S1041-6080(00)80003-5.

Ramos-Sánchez, L., \& Nichols, L. (2007). Self-efficacy of first-generation and non-first-generation college students: the relationship with academic performance and college adjustment. Journal of College Counseling, 10, 6-18. https://doi.org/10.1002/j.2161-1882.2007.tb00002.x.

Régner, I., Huguet, P., \& Monteil, J. (2002). Effects of socioeconomic status (SES) information on cognitive ability inferences: when low-SES students make use of a self-threatening stereotype. Social Psychology of Education, 5, 253-269. https://doi.org/10.1023/A:1016313908667.

Rubin, M. (2012). Social class differences in social integration among students in higher education: a meta-analysis and recommendations for future research. Journal of Diversity in Higher Education, 5(1), 22-38. https://doi.org/10.1037/a0026162.

Senko, C., Hulleman, C. S., \& Harackiewicz, J. M. (2011). Achievement goal theory at the crossroads: old controversies, current challenges, and new directions. Educational Psychologist, 46(1), 26-47. https://doi.org/10.1080/00461520.2011.538646.

Sirin, S. R. (2005). Socioeconomic status and academic achievement: a meta-analytic review of research. Review of Educational Research, 75, 417-453. https://doi.org/10.3102/00346543075003417.

Smeding, A., Darnon, C., Souchal, C., Toczek-Capelle, M.-C., \& Butera, F. (2013). Reducing the socioeconomic status achievement gap at university by promoting mastery-oriented assessment. PLOS ONE, 8, 1-6. https://doi.org/10.1371/journal.pone.0071678.

Smiley, P. A., \& Dweck, C. S. (1994). Individual differences in achievement goals among young children. Child Development, 65(6), 1723-1743. https://doi.org/10.1111/j.1467-8624.1994.tb00845.x.

Souchal, C., Toczek-Capelle, M. C., Darnon, C., Smeding, A., Butera, F., \& Martinot, D. (2014). Assessing does not mean threatening: Assessment as a key determinant of girls' and boys' performance in a 
science class. British Journal of Educational Psychology, 84, 125-136. https://doi.org/10.1111/bjep.12012.

Spencer, B., \& Castano, E. (2007). Social class is dead. Long live social class! Stereotype threat among low socioeconomic status individuals. Social Justice Research, 20, 418-432. https://doi.org/10.1007/s11211-007-0047-7.

Stebleton, M. J., \& Soria, K. M. (2012). Breaking down barriers: academic obstacles of first-generation students at research universities. The Learning and Assistance Review, 17(2), 7-19. Retrieved from https://nclca.wildapricot.org/resources/Documents/Publications/TLAR/Issues/17 2.pdf.

Stebleton, M. J., Soria, K. M., \& Huesman, R. L. (2014). First-generation students' sense of belonging, mental health, and use of counseling services at public research universities. Journal of College Counseling, 17(1), 6-20. https://doi.org/10.1002/j.2161-1882.2014.00044.x.

Steele-Johnson, D., Beauregard, R. S., Hoover, P. B., \& Schmidt, A. M. (2000). Goal orientation and task demand effects on motivation, affect, and performance. Journal of Applied Psychology, 85(5), 724738. https://doi.org/10.1037/0021-9010.85.5.724.

Stephens, N. M., Fryberg, S. A., Markus, H. R., Johnson, C. S., \& Covarrubias, R. (2012a). Unseen disadvantage: how American universities' focus on independence undermines the academic performance of first-generation college students. Journal of Personality and Social Psychology, 102(6), 1178-1197. https://doi.org/10.1037/a0027143.

Stephens, N. M., Markus, H. R., \& Phillips, L. T. (2014). Social class culture cycles: how three gateway contexts shape selves and fuel inequality. Annual Review of Psychology, 65, 611-634. https://doi.org/10.1146/annurev-psych-010213-115143.

Stephens, N. M., Townsend, S. S. M. M., Markus, H. R., \& Phillips, L. T. (2012b). A cultural mismatch: independent cultural norms produce greater increases in cortisol and more negative emotions among first- generation college students. Journal of Experimental Social Psychology, 48(6), 1389-1393. https://doi. org/10.1016/j.jesp.2012.07.008.

Stout, J. G., \& Dasgupta, N. (2013). Mastering one's destiny: mastery goals promote challenge and success despite social identity threat. Personality and Social Psychology Bulletin, 39(6), 748-762. https://doi. org/10.1177/0146167213481067.

Twenge, J. M., \& Campbell, W. K. (2002). Self-esteem and socioeconomic status: a meta-analytic review. Personality and Social Psychology Review, 6(1), 59-71. https://doi.org/10.1207/S15327957PSPR0601.

Utman, C. H. (1997). Performance effects of motivational state: a meta-analysis. Personality and Social Psychology Review, 1(2), 170-182. https://doi.org/10.1207/s15327957pspr0102 4.

Van Yperen, N. W., Blaga, M., \& Postmes, T. (2014). A meta-analysis of self-reported achievement goals and nonself-report performance across three achievement domains (work, sports, and education). PLoS One, 9(4), e93594. https://doi.org/10.1371/journal.pone.0093594.

Van Yperen, N. W., Blaga, M., \& Postmes, T. (2015). A meta-analysis of the impact of situationally induced achievement goals on task performance. Human Performance, 28, 165-182. https://doi.org/10./08959285.2015.1006772. 
Yzerbyt, V., Muller, D., \& Judd, C. M. (2004). Adjusting researchers' approach to adjustment: on the use of covariates when testing interactions. Journal of Experimental Social Psychology, 40, 424-431. https://doi. org/10.1016/j.jesp.2003.10.001. 